\title{
Health-Risk Factors and 8-Year Incidence of Kidney Disease in Transitional Thailand: Prospective Findings From a Large National Cohort Study
}

\author{
Prasutr Thawornchaisit, $\mathrm{MD}, \mathrm{PhD}^{1}$, Ferdinandus de Looze, MBBS, $\mathrm{MSc}^{2}$, Christopher M Reid, $\mathrm{PhD}^{3,4}$, \\ Sam-ang Seubsman, $\mathrm{PhD}^{5} \&$ Adrian Sleigh, $\mathrm{MD}^{6}$ \\ ${ }^{1}$ Department of Medical Services, Ministry of Public Health, Thailand \\ ${ }^{2}$ School of Medicine, University of Queensland, Australia \\ ${ }^{3}$ School of Public Health and Preventive Medicine, Monash University, Australia \\ ${ }^{4}$ School of Public Health, Curtin University, Perth, Australia \\ ${ }^{5}$ School of Human Ecology, Sukhothai Thammathirat Open University, Thailand \\ ${ }^{6}$ National Centre for Epidemiology and Population Health, Research School of Population Health, ANU College \\ of Health and Medicine, The Australian National University, Australia
}

Correspondence: Prasutr Thawornchaisit, Department of Medical Services, Ministry of Public Health, 88/23 Tiwanon Road. Amphoe Muang, Nonthaburi 11000, Thailand. Tel: 11-66-2590-6381; Fax: 11-66-2965-9863. E-mail: prasutt@yahoo.com

Received: November 6, 2017 Accepted: February 2, 2018 Online Published: February 19, 2018

doi:10.5539/gjhs.v10n3p132

URL: https://doi.org/10.5539/gjhs.v10n3p132

\begin{abstract}
Objective: Kidney disease (KD) is increasing its burden in Thailand but prospective observational KD studies are few. So we analysed 8-year nationwide Thai Cohort Study (TCS) data on KD incidence, distribution and risk association among Thais.
\end{abstract}

Design and Method: TCS is a longitudinal study of the Thai health-risk transition among Open University student residing nationwide. At baseline (2005) the cohort members analysed here were aged 15-88 years and did not have KD. At the follow up in $2013(\mathrm{n}=41638)$ incident $\mathrm{KD}$ was reported based on doctor diagnosis. We analysed the 8 -year cumulative incidence of KD and its association with risk factors by using multivariable logistic regression.

Results: The incidence of KD (2005 to 2013) was 4.0\%; the rate in men (5.9) was significantly higher than in women (2.5). KD increased significantly for both increasing age and body mass index (BMI) ( $p$ trend $<0.001$ for both). Its incidence was strongly associated with concurrent diseases including hypertension, diabetes and high blood lipids and moderately associated with increased frequency of cigarette smoking, instant food, roast or smoked food and soft drink consumption. KD decreased with increases in personal income, household assets, walking and physical activity.

Conclusion: Physical activity, high income and household assets prevented KD. Lifestyle changes such as smoking and high consumption of instant, roast or smoked food and soft drink increased risk of KD. Government should encourage more physical activity and less smoking, salt and sugar.

Keywords: kidney disease, socioeconomic status, body mass index, physical activity, Thailand, cohort

\section{Introduction}

Kidney disease (KD) is a worldwide public health burden that leads to end-stage renal disease (ESRD) and cardiovascular disease (CVD), with a large cumulative loss of disability-adjusted life years (DALYs). The prevalence of KD is increasing and estimated to range from $9 \%$ to $16 \%$ around the globe. Estimates have been reported from many countries such as Malaysia (Hooi et al., 2013), Norway (Hallan et al., 2006), China (Zhang et al., 2012), Taiwan (Wen et al., 2008), Japan (Imai et al., 2009), the US (Coresh et al., 2007) and Turkey (Suleymanlar et al., 2011). In addition, decreased glomerular filtration rate (GFR) in KD increases risk of CVD and decreases life expectancy (Gansevoort et al., 2013; Go, Chertow, Fan, McCulloch, \& Hsu, 2004; Keith, Nichols, Gullion, Brown, \& Smith, 2004). This is important because CVD is the dominant cause of mortality 
around the globe (Roth et al., 2015) particularly in those with KD (Drey, Roderick, Mullee, \& Rogerson, 2003). In the 2010 US Global Burden of Disease Study, KD was ranked as the 9th and17th cause of death and disability-adjusted life years, respectively (Murray \& Lopez, 2013).

In Thailand, KD prevalence is increasing rapidly (9\% in 2003 and $17.5 \%$ in 2008) (Chittinandana, Chailimpamontree, \& Chaloeiphap, 2006; Ingsathit et al., 2010). This may be a result of increased risks for KD in the Thai population due to ageing (Sasat \& Bowers, 2013), increasing obesity (Aekplakorn et al., 2014), diabetes (Papier et al., 2016) and hypertension (Thawornchaisit et al., 2013b). Thailand's rapid socio-economic development in the last 4 decades leads to urbanization (Lim, Kjellstrom, et al., 2009), and sedentary work. People consume more calories and more fat, sugar and salt (Aekplakorn et al., 2011; Lim et al., 2014; Pitayatienanan et al., 2014). Urbanization altered lifestyle with more alcohol consumption and a higher incidence of non-communicable diseases such as hypertension, high cholesterol and obesity (Wakabayashi et al., 2015).

Our 8-year prospective cohort analysis aims to identify the risk factors of KD operating in Thailand such as age, demography, socio-economy, physical activity, cigarette smoking, alcohol drinking, soft drink intake, food and vegetable consumption, concurrent diseases particularly hypertension, diabetes and high blood lipids. Finding the current risk factors of KD will help to develop the national policy for prevention of further burden from ESRD in the Thai population such as screening for early detection and appropriate interventions for controlling risk factors.

\section{Methods}

\subsection{Data and Study Population}

The Thai Cohort Study (TCS) is an on-going prospective study of the health-risk transition among distance learning Open University students. It investigates effects on population health of rapid socioeconomic development and modernization underway in Thailand (Sleigh, Seubsman, \& Bain, 2008). A 20-page baseline questionnaire was mailed to all 200000 students enrolled at Sukothai Thammathirat Open University in 2005. Overall 44\% (87151) responded and follow up mail-out questionnaires were completed in 2009 and 2013. Across those 8 years 42785 persons responded to all three surveys and constitute the cohort analysed here. These cohort members live in their communities nationwide and represent well the STOU student body and the general Thai adult population, with similar median age, median income, country-wide residence distribution and ethnic diversity (Seubsman, Yiengprugsawan, Sleigh, \& the Thai Cohort Study, 2012). However, they were also younger and better educated than most Thai adults and were expected to experience the health-risk transition ahead of their fellow Thais. Details on study methodology and cohort characteristics have been reported (Seubsman et al., 2012; Sleigh et al., 2008). Investigated risk factors included demographic, socioeconomic, cultural and lifestyle characteristics, health-risk behaviours, diet, body mass index and self-reported health outcomes including kidney disease, diabetes, high blood lipid, hypertension, various cancers, goiter, epilepsy, asthma, arthritis, chronic bronchitis, and depression/anxiety. As well there were questions on hearing, vision or dental impairment, occupation, home environment, health services, social networks, personal well-being and family background.

\subsection{Variables and Categories}

Analyses were carried out with kidney disease (KD) as the dependent outcome variable. Independent explanatory variables examined included demographic factors (age, marital status, urbanization) and SES (income, household assets, and education), body mass index (BMI), underlying disease (diabetes, high blood lipid and hypertension), and lifestyle factors (physical exercise, food preferences and intake, cigarette smoking and alcohol consumption) were independent variables.

Participants were grouped into three age categories. Marital status was defined as married/living with a partner or single. Urbanization status was classified based on rural $(\mathrm{R})$ or urban $(\mathrm{U})$ residence when aged 10-12 years old and in 2005 thus producing 4 groups: lifelong ruralites (RR), urbanizers (RU), de-urbanizers (UR) and urbanites (UU).

Personal monthly income was divided into four categories. In 2005, one US dollar was equivalent to 42 baht so most participants had quite low incomes. Household assets were classified into three categories.

Body mass index (BMI) was calculated and Asian cut-offs points for different body sizes were used, in accordance to guidelines of the International Obesity Task Force (Kanazawa et al., 2005). BMI classification was as follows: underweight (BMI $<18.5)$, normal $(18.5 \leq \mathrm{BMI}<23)$, overweight $(23 \leq \mathrm{BMI}<25)$, or obese $(\mathrm{BMI} \geq 25)$.

Screen time (hours/day spent before TV or computer) and sitting time (hours/day spent sitting for any purpose) were assessed as proxies for sedentariness. Incidental exercise (frequency of housework or gardening), was categorised into 4 groups: $\leq 3$ times per month; 1-2 times per week; 3-4 times per week; most days. Various forms of physical activity (at least 20 minutes of mild, moderate or strenuous exercise, 10 minutes or more walking 
sessions) were also included and recorded using 4-item ordinal categories ranging from never to $\geq 5$ times per week.

We measured planned total physical activity based on cohort members reporting the number of sessions per week of strenuous and moderate exercise for at least 20 minutes, and of walking for at least 10 minutes. We weighted the measures as follows: $(2 \times$ strenuous $+1 \times$ moderate $+1 \times$ walking $)$ sessions per week. This weighting system is based on the recommendation of the International Physical Activity Questionnaire and the Active Australia Survey as used in other analyses of cohort data (Australian Institute of Health and Welfare, 2003; Banks, Lim, Seubsman, Bain, \& Sleigh, 2011). Finally, for each individual, the 'overall measures' of weekly exercise for 2005 and 2013 were added and then averaged by dividing by 2 , creating a longitudinal measure of planned physical activity (LPPA).

Smoking was self-reported and grouped into never, ex-smoker or current smoker. Alcohol consumption had four categories: never, ex-drinker, occasional drinker or current-drinker. Foods that could potentially influence KD (deep fried, instant, roast or smoked, soybean products and soft drinks) were assessed for consumption frequency based on a five-point Likert scale ranging from less than once a month to once or more a day. Western-style fast food exposure was noted on a three-point scale from less than once to more than 3 times per month. Fruit and vegetable consumption were recorded as standard serves eaten per day.

\subsection{Statistical Analyses}

All analyses were performed using SPSS software. The 8-year KD risks were calculated for each explanatory variable. For statistical inference, $95 \%$ confidence intervals (CI) are presented as well as two tailed p-values with significance at 5 percent (one asterisk) or one percent (two asterisks).

Relative risks (RRs) in a large study of an uncommon disease (incidence less than 10\%) can be accurately estimated as odds ratios (ORs) (Webb \& Bain, 2011). For each risk variable, the RR and 95\% CI were estimated using logistic regression to calculate the bivariate OR for KD. Adjusted RRs (ARRs) were estimated by calculating multivariate logistic regression ORs. ARRs were controlled for confounding by age, sex, marital status, socioeconomic status (SES), BMI, underlying diseases and personal behaviours (cigarette smoking and alcohol drinking). A variable was included in a multivariate model if bivariate analysis had indicated a statistically significant association with incidence of KD. Some variables were included because earlier analyses reported elsewhere had shown a significant or substantial association with KD.

\section{Results}

\subsection{Baseline Characteristic of Participants}

TCS participants without KD at baseline in 2005 and responding in 2013 were analysed. The remaining cohort participants at risk were 41638 (Table 1). The mean age of participants at baseline was 32.5 years old and there were more females than males ( $55 \%$ vs $45 \%)$. The highest proportion of participants resided in the Central regions and North-eastern and the lowest proportion lived in the East. Sixty three percent of the participants lived in urban areas. More than half of participants had a higher education attainment than high school and their monthly incomes were lower than 10000 baht. The distribution of household assets of participants was quite similar to Thai population with a slightly higher proportion of participants in the low category. Overall, 1958 participants reported in 2013 being diagnosed with KD by a doctor (Table 2).

\subsection{Incidence and Risk Factors of KD}

The overall KD cumulative incidence between 2005 and 2013 was 4.0\% (1556/38754); the rate in males (5.9\%) was significantly higher than that of females $(2.5 \%$, Table 2$)$. The incidence directly rose with age and an increased BMI. However, the risk of KD decreased with the increased personal income and household assets. Marital status, urbanization and educational attainment had no influence on the risk of KD.

Walking and planned physical activity, averaged across the 8-year follow-up, were protective factors. The higher frequency of walking ( $\geq 4$ times/week) and LPPA ( $\geq 15$ sessions/week) were associated with lower incidence of KD The risk of KD increased in participants who had diabetes mellitus, high blood lipids and hypertension. Current smokers and ex-smokers had a higher risk of developing KD than non-smokers. However alcohol drinking had no influence on the risk of incident KD. The risk of KD had a direct association with the frequency of instant and roast or smoked food consumption and drinking soft drinks while fruit and vegetable intake had no influence on KD. 
Table 1. Attributes of 41638 Thai Cohort Study members who did not have kidney disease at study baseline in 2005

\begin{tabular}{|c|c|c|}
\hline \multirow{2}{*}{ Factor } & \multicolumn{2}{|c|}{ Participants } \\
\hline & $\mathrm{n}$ & percent \\
\hline \multicolumn{3}{|l|}{ Demographic data } \\
\hline Participants & 41638 & \\
\hline Age $(y)$ mean & 32.5 & \\
\hline$(\mathrm{SD})$ & $(8.5)$ & \\
\hline \multicolumn{3}{|l|}{ Age group } \\
\hline$\leq 30 \mathrm{y}$ & 19694 & 47.3 \\
\hline $31-40 y$ & 14517 & 34.9 \\
\hline$>40 \mathrm{y}$ & 7427 & 17.8 \\
\hline \multicolumn{3}{|l|}{ Sex } \\
\hline Male & 18798 & 45.1 \\
\hline Female & 22840 & 54.9 \\
\hline \multicolumn{3}{|l|}{ Married/partnered } \\
\hline No & 19098 & 53 \\
\hline Yes & 21499 & 47 \\
\hline \multicolumn{3}{|l|}{ Regions } \\
\hline Bangkok & 6821 & 16.5 \\
\hline Central & 9969 & 24.1 \\
\hline North & 8333 & 20.1 \\
\hline North-east & 8695 & 21.0 \\
\hline East & 2409 & 5.8 \\
\hline South & 5186 & 12.5 \\
\hline \multicolumn{3}{|l|}{ Urbanization status $^{\mathrm{a}}$} \\
\hline Rural-rural (RR) & 2553 & 18.9 \\
\hline Rural-urban (RU) & 3846 & 28.5 \\
\hline Urban-rural (UR) & 2402 & 17.8 \\
\hline Urban-urban (UU) & 4678 & 34.7 \\
\hline \multicolumn{3}{|l|}{ Socioeconomic status } \\
\hline \multicolumn{3}{|l|}{ Education level } \\
\hline High school & 18361 & 44.2 \\
\hline Diploma & 11090 & 26.7 \\
\hline University & 12086 & 29.1 \\
\hline \multicolumn{3}{|c|}{ Personal monthly income (baht) } \\
\hline$\leq 7000$ & 14740 & 36.1 \\
\hline $7001-10000$ & 9324 & 22.8 \\
\hline $10001-20000$ & 11559 & 28.3 \\
\hline$>20000$ & 5213 & 12.8 \\
\hline \multicolumn{3}{|c|}{ Household assets $^{\mathrm{e}}$ (baht) ${ }^{\mathrm{d}}$} \\
\hline Low & 15340 & 36.8 \\
\hline Medium & 13192 & 31.7 \\
\hline High & 12937 & 31.1 \\
\hline
\end{tabular}


Table 2. Eight-year incidence of kidney disease and association with baseline risk factors among Thai Cohort Study participants, 2005-2013

\begin{tabular}{|c|c|c|c|}
\hline & $\mathrm{KD}^{\mathrm{a}}(\mathrm{n})$ & I $\%(95 \% \text { CI })^{b}$ & aRR $(95 \% \mathrm{CI})$ \\
\hline Participants & 1958 & $4.0(3.8-4.2)$ & \\
\hline \multicolumn{4}{|c|}{ Demography } \\
\hline \multicolumn{4}{|l|}{ Age group } \\
\hline$\leq 30 \mathrm{y}$ & 530 & $2.8(2.6-3.0)$ & 1 \\
\hline $31-40 y$ & 602 & $4.5(4.1-4.9)$ & $1.59(1.36-1.86)$ \\
\hline$>40 \mathrm{y}$ & 424 & $6.4(5.8-7.0)$ & $2.18(1.77-2.67)$ \\
\hline P-trend & & & $<0.0001$ \\
\hline \multicolumn{4}{|l|}{ Sex } \\
\hline Female & 529 & $2.5(2.3-2.7)$ & 1 \\
\hline Male & 1027 & $5.9(5.5-6.3)$ & $1.62(1.38-1.9)$ \\
\hline
\end{tabular}

\section{Socio-economic status}

\section{Education level}

\begin{tabular}{llcc} 
University & 770 & $4.6(4.2-5.0)$ & 1 \\
Diploma & 360 & $3.5(3.1-3.9)$ & $1.07(0.91-1.26)$ \\
High school & 423 & $3.7(5.2-5.9)$ & $1.17(0.83-1.12)$ \\
\hline P-trend & & 0.381
\end{tabular}

\section{Personal monthly income (baht)}

\begin{tabular}{|c|c|c|c|}
\hline$\leq 7000$ & 486 & $3.6(3.2-4.1)$ & 1 \\
\hline $7001-10000$ & 333 & $3.8(3.4-4.2)$ & $0.88(0.74-1.03)$ \\
\hline $10001-20000$ & 469 & $4.3(3.9-4.7)$ & $0.73(0.61-0.87)$ \\
\hline$>20000$ & 238 & $4.9(4.3-5.5)$ & $0.71(0.56-0.89)$ \\
\hline P-trend & & & $<0.004$ \\
\hline \multicolumn{4}{|l|}{ Household asset } \\
\hline Low & 548 & $3.9(6.6-7.5)$ & 1 \\
\hline Medium & 494 & $4.0(4.6-5.3)$ & $0.93(0.81-1.08)$ \\
\hline High & 508 & $4.2(3.3-3.9)$ & $0.86(0.73-1.0)$ \\
\hline P-trend & & & 0.208 \\
\hline \multicolumn{4}{|l|}{ BMI classification } \\
\hline $\begin{array}{l}\text { Underweight } \\
(\mathrm{BMI}<18.5)\end{array}$ & 109 & $2.2(1.8-2.6)$ & $0.78(0.61-0.99)$ \\
\hline $\begin{array}{l}\text { Normal } \\
(18.5 \leq \mathrm{BMI}<23)\end{array}$ & 634 & $3.1(2.9-3.3)$ & 1 \\
\hline $\begin{array}{l}\text { Overweight } \\
(23 \leq \mathrm{BMI}<25)\end{array}$ & 296 & $4.7(4.1-5.3)$ & $1.31(1.12-1.56)$ \\
\hline $\begin{array}{l}\text { Obese } \\
(\mathrm{BMI} \geq 25)\end{array}$ & 490 & $7.6(7.0-8.2)$ & $1.9(1.64-2.2)$ \\
\hline P-trend & & & $<0.0001$ \\
\hline
\end{tabular}




\begin{tabular}{|c|c|c|c|}
\hline \multicolumn{4}{|c|}{ Physical activities } \\
\hline \multicolumn{4}{|c|}{ Walking per week } \\
\hline Never & 249 & $3.8(3.4-4.2)$ & 1 \\
\hline 1-3 times & 375 & $4.0(3.6-4.4)$ & $0.9(0.75-1.08)$ \\
\hline 4-6 times & 398 & $4.2(3.8-4.6)$ & $0.79(0.65-0.95)$ \\
\hline$\geq 7$ times & 484 & $4.1(3.7-4.5)$ & $0.82(0.68-0.99)$ \\
\hline P-trend & & & .068 \\
\hline $0-7 \mathrm{ses} / \mathrm{w}^{\mathrm{e}}$ & 552 & $5.2(4.8-5.7)$ & 1 \\
\hline $8-14 \mathrm{ses} / \mathrm{w}$ & 653 & $5.0(4.6-5.3)$ & 0.94 (0.81-1.09) \\
\hline$\geq 15$ ses $/ w$ & 495 & $4.9(4.5-5.3)$ & $0.89(0.75-1.0)$ \\
\hline P-trend & & & 0.582 \\
\hline
\end{tabular}

Table 2. (continued...)

\begin{tabular}{|c|c|c|c|}
\hline & $\mathrm{KD}^{\mathrm{a}}(\mathrm{n})$ & I $\%(95 \% \text { CI })^{b}$ & $\operatorname{aRR}(95 \% \mathrm{CI})^{\mathrm{c}}$ \\
\hline \multicolumn{4}{|c|}{ Underlying diseases } \\
\hline \multicolumn{4}{|c|}{ Diabetes mellitus (type1\&2) } \\
\hline No & 1474 & $3.8(3.6-4.0)$ & 1 \\
\hline Yes & 82 & $19.1(19.0-19.14)$ & $2.59(1.9-3.53)$ \\
\hline \multicolumn{4}{|c|}{ High lipids } \\
\hline No & 1247 & $3.6(3.4-3.8)$ & 1 \\
\hline Yes & 309 & $7.4(6.6-8.2)$ & $1.43(1.21-1.68)$ \\
\hline \multicolumn{4}{|c|}{ Hypertension } \\
\hline No & 1355 & $3.7(3.5-3.9)$ & 1 \\
\hline Yes & 201 & $10.8(9.4-12.2)$ & $1.86(1.54-2.26)$ \\
\hline
\end{tabular}

\begin{tabular}{|c|c|c|c|}
\hline \multicolumn{4}{|c|}{ Personal behaviours } \\
\hline \multicolumn{4}{|l|}{ Smoking status } \\
\hline Never & 847 & $3.0(2.8-3.2)$ & 1 \\
\hline Ex-smoker & 444 & $6.6(6.0-7.2)$ & $1.277(1.09-1.5)$ \\
\hline Smoker $^{\mathrm{f}}$ & 230 & $7.4(6.4-8.5)$ & $1.49(1.23-1.8)$ \\
\hline P-trend & & & $<0.0001$ \\
\hline \multicolumn{4}{|l|}{ Drinking status } \\
\hline Never & 272 & $2.6(2.2-3.0)$ & 1 \\
\hline Ex-drinker & 169 & $5.3(4.5-6.1)$ & $1.35(1.07-1.7)$ \\
\hline Occ- drinker ${ }^{\mathrm{g}}$ & 926 & $4.1(3.9-4.3)$ & $1.07(0.91-1.27)$ \\
\hline Reg- drinker ${ }^{\mathrm{h}}$ & 174 & $9.3(7.9-10.7)$ & $1.52(1.18-1.97)$ \\
\hline P-trend & & & $<0.001$ \\
\hline \multicolumn{4}{|c|}{ Food consumption habit } \\
\hline \multicolumn{4}{|l|}{ Instant food } \\
\hline$<1$ time $/ \mathrm{m}$ & 330 & $4.0(3.6-4.4)$ & 1 \\
\hline $1-3$ times $/ \mathrm{m}$ & 591 & $3.8(3.4-4.2)$ & $1.03(0.88-1.22)$ \\
\hline 1-2 times/wk & 361 & $3.8(3.4-4.2)$ & $1.03(0.86-1.24)$ \\
\hline
\end{tabular}




\begin{tabular}{|c|c|c|c|}
\hline 3-6 times/wk & 211 & $4.6(4.0-5.2)$ & $1.3(1.04-1.62)$ \\
\hline$\geq 1$ times $/ \mathrm{d}$ & 45 & $5.4(3.8-7.0)$ & $1.43(0.97-2.12)$ \\
\hline P-trend & & & .066 \\
\hline \multicolumn{4}{|c|}{ Roast or smoked food } \\
\hline$<1$ time $/ \mathrm{m}$ & 218 & $3.5(3.1-3.9)$ & 1 \\
\hline $1-3$ times $/ \mathrm{m}$ & 512 & $3.6(3.2-4.0)$ & $1.11(0.91-1.34)$ \\
\hline $1-2$ times/wk & 462 & $4.0(3.6-4.4)$ & $1.2(0.97-1.47)$ \\
\hline 3-6 times/wk & 296 & $5.3(4.7-5.9)$ & $1.39(1.10-1.76)$ \\
\hline$\geq 1$ times/d & 49 & $5.9(4.3-7.5)$ & $1.62(1.1-2.39)$ \\
\hline P-trend & & & $<0.025$ \\
\hline \multicolumn{4}{|l|}{ Soft drink } \\
\hline$<1$ time $/ \mathrm{m}$ & 335 & $3.2(2.8-3.6)$ & 1 \\
\hline $1-3$ times $/ \mathrm{m}$ & 453 & $4.0(3.6-4.4)$ & $1.15(0.97-1.35)$ \\
\hline $1-2$ times/wk & 344 & $4.0(3.6-4.4)$ & $1.08(0.9-1.29)$ \\
\hline 3-6 times/wk & 282 & $4.8(4.2-5.4)$ & $1.29(1.06-1.57)$ \\
\hline$\geq 1$ times $/ \mathrm{d}$ & 123 & $5.3(4.3-6.3)$ & $1.4(1.07-1.81)$ \\
\hline P-trend & & & 0.04 \\
\hline
\end{tabular}

${ }^{\mathrm{a}}$ Kidney disease. ${ }^{\mathrm{b}}$ Incidence of kidney disease and 95\% confidence intervals (CIs). ${ }^{\mathrm{c}}$ Adjusted relative risks and $95 \%$ CIs calculated from multi-variable logistic regression models of kidney disease adjusted for age, sex, marital status, socioeconomic status (exclude type of house), BMI classification, sedentariness, physical activities, underlying diseases and personal behaviours. ${ }^{\mathrm{d}}$ Asian standard BMI classification. ${ }^{\mathrm{e}}$ Sessions/week. ${ }^{\mathrm{f}}$ Current smoker. ${ }^{\mathrm{g}}$ Occasional drinker. ${ }^{\mathrm{h}}$ Regular drinker

\section{Discussion}

Our large national cohort study of the Thai health-risk transition produce data on the incidence of kidney disease and its risks in young and middle-aged Thai adults. The 8-year follow up from 2005 to 2013 of participating cohort members who were initially free of KD detected a cumulative incidence of KD over this period of $4 \%$. Risk factors that were strongly associated with higher incidence of KD were male sex, ageing, obesity, concurrent diseases (particularly diabetes, high blood lipids and hypertension). Factors inversely related to the incidence of KD were personal income and household assets. Cigarette smoking, instant food, roast or smoked food and soft drinks consumption had a moderate effect on KD incidence but walking 4 or more times per week inversely affected incident KD. Planned physical activity averaging 15 or more sessions per week over the 8 -year period reduced the incidence of KD. Urbanization, marital or partner status and education attainment had no influence on KD. As well alcohol drinking, fruit and vegetable consumption were not related to KD. The incidence of KD in this cohort was much lower than those in other studies (Ingsathit et al., 2010) since the TCS participants were younger than general Thai adults.

In our cohort study, ageing was a strong risk of KD incidence which was consistent with previous cross-sectional studies in China (Du et al., 2017; C. Xue et al., 2013; Zhang et al., 2012), Korea (Kim et al., 2009; Park, Baek, \& Jung, 2016), Thailand (Thawornchaisit et al., 2015), Malaysia (Hooi et al., 2013), Singapore (Ramirez, McClellan, Port, \& Hsu, 2002), India (Anupama \& Uma, 2014), Turkey (Suleymanlar et al., 2011) and the US (White et al., 2008). Age was independently associated with a reduced renal function (W. Chen et al., 2009; Zhang et al., 2008; Zhang et al., 2007) and albuminuria (W. Chen et al., 2009). One study showed that an increase in 1 year in age carries $4 \%$ chance of getting KD (Anupama \& Uma, 2014). In conclusion, age is an independent risk factor for KD. Sex is also an important factor. This Thai cohort found that males had a significantly higher risk of KD compared to females. Similar results were reported from China (Zhang et al., 2012), India (Anupama \& Uma, 2014) and the US (Coresh, Astor, Greene, Eknoyan, \& Levey, 2003; Coresh et al., 2005). A study in Japan showed males had a higher risk for low estimated glomerular filtration rate (eGFR) (Takamatsu et al., 2009). A study in China found females also had a high risk of reduced eGFR (L. Xue et al., 2014). Many cross-sectional studies in China (J. Chen et al., 2005; Du et al., 2017; L. Xue et al., 2014), Thailand (Ingsathit et al., 2010), Turkey (Suleymanlar et al., 2011), 
Australia (White et al., 2008) and the US (Brown et al., 2003) found being female was an independent risk factor for KD.

Socio-economic status (SES), particularly personal monthly income and household assets, had an inverse effect on risk of KD. Similar results emerged from cross-sectional studies in China (Du et al., 2017), Taiwan (Wen et al., 2008), Thailand (Perkovic et al., 2008) and the US (Martins et al., 2006; Vart, Gansevoort, Coresh, Reijneveld, \& Bultmann, 2013; White et al., 2008). One of these studies in the US revealed that poverty associated with increase risk of microalbuminuria (Martins et al., 2006). Low SES people tend to have increased risk of obesity and hypertension (Vart et al., 2013) as well as more infection, more interstitial and glomerulonephritis, poor diet and environment and low opportunity to access health care due to lack of health insurance (White et al., 2008). The progress of the health risk transition in Thailand is revealing that KD and SES already associate inversely as in rich countries.

We also found that increasing BMI was directly associated with increasing incident KD. Similar results were revealed in previous cross-sectional studies in Korea (Kim et al., 2009; Park et al., 2016), China (Du et al., 2017), Singapore (Ramirez et al., 2002) and Australia (White et al., 2008) and in follow up studies of 10 to 12 years in the US (Grubbs et al., 2014; Stengel, Tarver-Carr, Powe, Eberhardt, \& Brancati, 2003) and 25 years in Israeli (Vivante et al., 2012). The US study of Grubbs et al (2014) found that increasing BMI was significantly associated with lower kidney function. In Singapore a higher BMI associated with rising proteinuria (Ramirez et al., 2002). In a prospective cohort of Israeli soldiers obesity was significantly associated with an increased risk of incident ESRD (Vivante et al., 2012). A British cohort study revealed that obesity when young (less than 40 years) was significantly associated with a higher risk of KD incidence (Silverwood et al., 2013). Multiple studies have shown obesity is a risk for $\mathrm{KD}$ which then becomes part of the enormous national cost of excess weight (W. Chen et al., 2009; Du et al., 2017; Pitayatienanan et al., 2014; L. Xue et al., 2014).

Our cohort found that higher frequency of walking and LPPA was associated with a reduction of KD incidence. Our previous cross-sectional study of baseline TCS data also revealed a similar result of LPPA (Thawornchaisit et al., 2015). It is consistent with previous study revealing that physical inactivity related to an increase risk of KD incidence (Stengel et al., 2003). In addition, a study in KD patients reported that regular water-based exercise (30 minutes, twice a week) associated with decrease of proteinuria and increase of glomerular filtration rate (Pechter et al., 2003).

We found that diabetes mellitus was a strong risk factor for KD as noted in cross-sectional studies in China (C. Xue et al., 2013; Zhang et al., 2012), Korea (Kim et al., 2009; Park et al., 2016), Malaysia (Hooi et al., 2013), Singapore (Ramirez et al., 2002), Thailand (Ingsathit et al., 2010; Thawornchaisit et al., 2015), India (Anupama \& Uma, 2014), the US, Australia and Thailand (White et al., 2008). In China, a population based cross-sectional study indicated that diabetes was the strongest risk factor for KD (W. Chen et al., 2009; L. Xue et al., 2014). A study in Singapore revealed that diabetes associated with increase of proteinuria (Ramirez et al., 2002). The most common cause of KD was glomerulonephritis and the second was diabetic nephropathy (Xie \& Chen, 2008). The study revealed that blood sugar $(\mathrm{HbA} 1 \mathrm{c})$ in diabetes patients was associated with an increase of albuminuria, predictor of microvascular lesions for kidney disease including ESRD (Parving et al., 2006). In addition, population-based studies in China confirmed that diabetes associated with an increase of albuminuria (W. Chen et al., 2009; L. Xue et al., 2014) while one study reported that diabetes associated with reduction of eGFR (L. Xue et al., 2014).

We found that high blood lipids strongly associated with increased KD incidence. Cross-sectional evidence from Thailand (Thawornchaisit et al., 2015) and China (W. Chen et al., 2009; W. Chen et al., 2011; C. Xue et al., 2013; L. Xue et al., 2014; Zhang et al., 2007) and prospective evidence from the US (Muntner, Coresh, Smith, Eckfeldt, \& Klag, 2000) revealed similar results. High blood cholesterol and triglyceride associated with a reduced renal fuction (Zhang et al., 2007). High triglyceride (W. Chen et al., 2009) and lipid (L. Xue et al., 2014) associated with increase of albuminuria. One of these studies revealed that high lipid and cholesterol associated with reduction of eGFR and high risk of KD (L. Xue et al., 2014). High triglycerides and lower high-density lipoprotein (HDL) cholesterol related to increased KD incidence (Muntner et al., 2000). Hyperlipidaemia may have a major role in increased risk of glomerulosclerosis and tubule-interstitial fibrosis (Schaeffner et al., 2003).

In the Thai Cohort Study, hypertension was strongly associated with a higher incident KD and similar findings were reported from cross-sectional studies in China (Du et al., 2017; C. Xue et al., 2013; L. Xue et al., 2014; Zhang et al., 2012), Korea (Kim et al., 2009; Park et al., 2016), Malaysia (Hooi et al., 2013), Singapore (Ramirez et al., 2002), Thailand (Ingsathit et al., 2010; Thawornchaisit et al., 2015), India (Anupama \& Uma, 2014), the US, Australia and Thailand (White et al., 2008). High blood pressure associated with reduced renal fuction (W. Chen et al., 2009; Zhang et al., 2008; Zhang et al., 2007). A study in Singapore revealed that hypertension associated with 
increase of proteinuria and the risk for proteinuria according to systolic and diastolic blood pressure were significantly increased beginning at levels of 110 and $90 \mathrm{mmHg}$, respectively (Ramirez et al., 2002). Hypertensive nephrosclerosis was the third most common causes of KD (Xie \& Chen, 2008). High blood pressure (L. Xue et al., 2014) and hypertension (W. Chen et al., 2009; W. Chen et al., 2011) were independent risk of increased albuminuria. As well hypertension associated with a reduction of eGFR (W. Chen et al., 2011). In addition, blood pressure in diabetes patients was associated with an increase of albuminuria which was an independent predictor of microvascular lesions for kidney disease including ESRD (Parving et al., 2006). Elevated systolic blood pressure in KD patients was a significantly risk factor associated with KD progression to ESRD (Inaguma et al., 2017). The population-based studies in China found that hypertension independently associated with KD occurrence (W. Chen et al., 2009; W. Chen et al., 2011).

In our cohort, cigarette smoking is moderately associated with an increased risk of KD incidence. Cross-sectional studies in China (W. Chen et al., 2009; C. Xue et al., 2013; L. Xue et al., 2014), Thailand (Thawornchaisit et al., 2015), The Netherlands (Pinto-Sietsma et al., 2000) and a longitudinal study in the US (Stengel et al., 2003) showed a similar result. The population-based studies in China found that cigarette smoking independently associated with increase albuminuria (L. Xue et al., 2014) and reduced renal function with the occurrence of KD (W. Chen et al., 2009). The study showed that smoking more than 20 cigarettes a day significantly related to two times risk of incidence of KD compared to non-smoker (Stengel et al., 2003). In addition, the Netherlands study revealed that smoking was associated with increase of albuminuria and reduction of GFR in a dose-response manner (Pinto-Sietsma et al., 2000). In sum, cigarette smoking was directly related with increased risk of KD incidence.

In our study, higher frequency of instant foods, high sodium intake and carbohydrate consumption were associated with a higher risk of incident KD. High salt consumption associated with increased risk of KD is reported in many studies such as in the US (Lin, Hu, \& Curhan, 2010), and Iran (Khaledifar, Gharipour, Bahonar, Sarrafzadegan, \& Khosravi, 2013). In women study, high sodium consumption associated with reduction of eGFR (Lin et al., 2010). High sodium intake may related with high blood pressure which also plays a major role in reduction of eGFR (Lin et al., 2010). A positive correlation between 24 hour urinary sodium secretion and the level of albuminuria was reported in an Iranian study (Khaledifar et al., 2013). Our study provides additional evidence that higher instant food consumption is associated with an increased $\mathrm{KD}$ incidence.

In our cohort, consumption of roast or smoked food, contained high protein associated with an increased incidence of KD which was consistent with several other studies (Jacobsen, Christensen, Mogensen, Andreasen, \& Heilskov, 1979; Jha et al., 2013) (Friedman, 2004). However, the Mediterranean diet associated with reducing the risk of development of KD (Chrysohoou et al., 2010). High protein consumption associated with glomerular hyperfiltration, increase of proteinuria and accelerated risk of KD (Friedman, 2004). In addition, a study of women with mild kidney insufficiency showed high protein intake related with reduction of kidney function (Knight, Stampfer, Hankinson, Spiegelman, \& Curhan, 2003). Furthermore, high consumption of red meat may increase risk for albuminuria (Lin et al., 2010). As well, in non-dialysis KD patients, low protein diet consumption was able to improve serum creatinine and increased eGFR (Rizzetto, Leal, Bastos, Fouque, \& Mafra, 2017). Many reports and our findings support that high protein consumption associated with increased risk of KD incidence.

We found that higher frequency of soft drink drinking directly increased risk of KD incidence. Our finding is consistent with previous reports such as cross-sectional studies in the US (Bomback et al., 2010; Saldana, Basso, Darden, \& Sandler, 2007; Shoham et al., 2008). The studies reported a significant association between two or more sugar-sweetened soft drinks per day intake and the increase of albuminuria (Shoham et al., 2008) and decline of eGFR (Lin \& Curhan, 2011). Furthermore, 2 or more cola carbonated beverages drinking per day was associated with increased risk of kidney disease (Saldana et al., 2007). As well, sugar-sweetened soda consumption one or more per day was associated with prevalent hyperuricemia and renal injury (Bomback et al., 2010). High serum uric acid level is an independent risk factor for incident kidney disease (Tsai, Lin, Kuo, \& Huang, 2017; Weiner et al., 2008). We found that frequent sugar-sweetened beverage intake related to increase risk of KD incidence.

Our cohort study is based on a very large and long-time prospective study of Thais. The results are adjusted for confounding factors so independent risk factors for $\mathrm{KD}$ for Thais can be identified. Although the participants are younger and well-educated than Thai people, they represent the population well in socio-demography, socio-economy and geography (Seubsman et al., 2012; Sleigh et al., 2008). Therefore, results from our studies will represent the future trends for renal health in the Thai population.

Self-report is a limitation of our cohort study since it may relate to recall error. We do know that these open university student populations accurately self-reported weight and height (Lim, Seubsman, \& Sleigh, 2009). 
Furthermore, cohort members accurately reported diabetes, heat exposure at work and hypertension (Papier et al., 2017; Tawatsupa et al., 2013; Thawornchaisit et al., 2013a). These validation studies show that self-report of health and disease by STOU participants is generally reliable for evaluating the health risk transition and the future trend of chronic diseases in Thailand. Indeed, the cohort study was conducted among Open University students to increase the reliability of self-reported measurement and each time we investigate a specific variable we find the report to be accurate.

\section{Acknowledgements}

\section{Funding and support}

This study was supported by the International Collaborative Research Grants Scheme, with joint grants from the Wellcome Trust UK (GR071587MA) and the Australian NHMRC (268055), and by a global health grant from the NHMRC (585426). We thank the Thai Cohort Study team at Sukhothai Thammathirat Open University (STOU) and the STOU students participating in the study. We also thank Dr Bandit Thinkamrop and his data team from Khon Kaen University for guiding us successfully through data processing.

\section{Thai Cohort Study Team}

Thailand: Jaruwan Chokhanapitak, Suttanit Hounthasarn, Suwanee Khamman, Daoruang Pandee, Suttinan Pangsap, Tippawan Prapamontol, Janya Puengson, Sam-ang Seubsman, Boonchai Somboonsook, Nintita Sripaiboonkij, Pathumvadee Somsamai, Prasutr Thawornchaisit, Duangkae Vilainerun, Wanee Wimonwattanaphan, Cha-aim Pachanee, Arunrat Tangmunkongvorakul, Benjawan Tawatsupa, Wimalin Rimpeekool.

Australia: Chris Bain, Emily Banks, Cathy Banwell, Bruce Caldwell, Gordon Carmichael, Tarie Dellora, Jane Dixon, Sharon Friel, David Harley, Matthew Kelly, Tord Kjellstrom, Lynette Lim, Anthony McMichael, Tanya Mark, Adrian Sleigh, Lyndall Strazdins, Vasoontara Yiengprugsawan, Susan Jordan, Janneke Berecki-Gisolf, Rod McClure.

\section{Ethical Considerations}

Ethical approval was obtained from Sukhothai Thammathirat Open University Research and Development Institute (protocol 0522/10) and the Australian National University Human Research Ethics Committee (protocol 2004344 and 2009570). Informed, written consent was obtained from all participants.

\section{Competing Interests Statement}

The authors declare that there are no competing or potential conflicts of interest.

\section{References}

Aekplakorn, W., Chariyalertsak, S., Kessomboon, P., Sangthong, R., Inthawong, R., Putwatana, P., . . . Thai National Health Examination Survey, I. V. S. G. (2011). Prevalence and management of diabetes and metabolic risk factors in Thai adults: the Thai National Health Examination Survey IV, 2009. Diabetes Care, 34(9), 1980-1985. https://doi.org/10.2337/dc11-0099

Aekplakorn, W., Inthawong, R., Kessomboon, P., Sangthong, R., Chariyalertsak, S., Putwatana, P., \& Taneepanichskul, S. (2014). Prevalence and trends of obesity and association with socioeconomic status in Thai adults: National Health Examination Surveys, 1991-2009. $J$ Obes, 2014, 410259. https://doi.org/10.1155/2014/410259

Anupama, Y. J., \& Uma, G. (2014). Prevalence of chronic kidney disease among adults in a rural community in South India: Results from the kidney disease screening (KIDS) project. Indian J Nephrol, 24(4), 214-221. https://doi.org/10.4103/0971-4065.132990

Australian Institute of Health and Welfare. (2003). The Active Australia Survey: A guide and manual for implementation, analysis and reporting Canberra. AIHW.

Banks, E., Lim, L., Seubsman, S. A., Bain, C., \& Sleigh, A. (2011). Relationship of obesity to physical activity, domestic activities, and sedentary behaviours: cross-sectional findings from a national cohort of over 70,000 Thai adults. BMC Public Health, 11, 762. https://doi.org/10.1186/1471-2458-11-762

Bomback, A. S., Derebail, V. K., Shoham, D. A., Anderson, C. A., Steffen, L. M., Rosamond, W. D., \& Kshirsagar, A. V. (2010). Sugar-sweetened soda consumption, hyperuricemia, and kidney disease. Kidney Int, 77(7), 609-616. https://doi.org/10.1038/ki.2009.500

Brown, W. W., Peters, R. M., Ohmit, S. E., Keane, W. F., Collins, A., Chen, S. C., . . Flack, J. M. (2003). Early 
detection of kidney disease in community settings: the Kidney Early Evaluation Program (KEEP). Am $J$ Kidney Dis, 42(1), 22-35.

Chen, J., Wildman, R. P., Gu, D., Kusek, J. W., Spruill, M., Reynolds, K., . . He, J. (2005). Prevalence of decreased kidney function in Chinese adults aged 35 to 74 years. Kidney Int, 68(6), 2837-2845. https://doi.org/10.1111/j.1523-1755.2005.00757.x

Chen, W., Chen, W., Wang, H., Dong, X., Liu, Q., Mao, H., . . Yu, X. (2009). Prevalence and risk factors associated with chronic kidney disease in an adult population from southern China. Nephrol Dial Transplant, 24(4), 1205-1212. https://doi.org/10.1093/ndt/gfn604

Chen, W., Liu, Q., Wang, H., Chen, W., Johnson, R. J., Dong, X., . . Yu, X. (2011). Prevalence and risk factors of chronic kidney disease: a population study in the Tibetan population. Nephrol Dial Transplant, 26(5), 1592-1599. https://doi.org/10.1093/ndt/gfq608

Chittinandana, A., Chailimpamontree, W., \& Chaloeiphap, P. (2006). Prevalence of chronic kidney disease in Thai adult population. J Med Assoc Thai, 89(Suppl 2), S112-120.

Chrysohoou, C., Panagiotakos, D. B., Pitsavos, C., Skoumas, J., Zeimbekis, A., Kastorini, C. M., \& Stefanadis, C. (2010). Adherence to the Mediterranean diet is associated with renal function among healthy adults: The ATTICA study. J Ren Nutr, 20(3), 176-184. https://doi.org/10.1053/j.jrn.2009.08.006

Coresh, J., Astor, B. C., Greene, T., Eknoyan, G., \& Levey, A. S. (2003). Prevalence of chronic kidney disease and decreased kidney function in the adult US population: Third National Health and Nutrition Examination Survey. Am J Kidney Dis, 41(1), 1-12. https://doi.org/10.1053/ajkd.2003.50007

Coresh, J., Byrd-Holt, D., Astor, B. C., Briggs, J. P., Eggers, P. W., Lacher, D. A., \& Hostetter, T. H. (2005). Chronic kidney disease awareness, prevalence, and trends among U.S. adults, 1999 to 2000. J Am Soc Nephrol, 16(1), 180-188. https://doi.org/10.1681/ASN.2004070539

Coresh, J., Selvin, E., Stevens, L. A., Manzi, J., Kusek, J. W., Eggers, P., . . Levey, A. S. (2007). Prevalence of chronic kidney disease in the United States. JAMA, 298(17), 2038-2047. https://doi.org/10.1001/jama.298.17.2038

Drey, N., Roderick, P., Mullee, M., \& Rogerson, M. (2003). A population-based study of the incidence and outcomes of diagnosed chronic kidney disease. Am J Kidney Dis, 42(4), 677-684.

Du, Y., Zhang, S., Hu, M., Wang, Q., Shen, H., Zhang, Y., . . Meng, Q. (2017). Prevalence of chronic kidney disease markers: Evidence from a three-million married population with fertility desire in rural China. Sci Rep, 7(1), 2710. https://doi.org/10.1038/s41598-017-02355-2

Friedman, A. N. (2004). High-protein diets: potential effects on the kidney in renal health and disease. Am $J$ Kidney Dis, 44(6), 950-962.

Gansevoort, R. T., Correa-Rotter, R., Hemmelgarn, B. R., Jafar, T. H., Heerspink, H. J., Mann, J. F., . . Wen, C. P. (2013). Chronic kidney disease and cardiovascular risk: epidemiology, mechanisms, and prevention. Lancet, 382(9889), 339-352. https://doi.org/10.1016/S0140-6736(13)60595-4

Go, A. S., Chertow, G. M., Fan, D., McCulloch, C. E., \& Hsu, C. Y. (2004). Chronic kidney disease and the risks of death, cardiovascular events, and hospitalization. $N$ Engl $J$ Med, 351(13), 1296-1305. https://doi.org/10.1056/NEJMoa041031

Grubbs, V., Lin, F., Vittinghoff, E., Shlipak, M. G., Peralta, C. A., Bansal, N., . . Bibbins-Domingo, K. (2014). Body mass index and early kidney function decline in young adults: a longitudinal analysis of the CARDIA (Coronary Artery Risk Development in Young Adults) study. Am J Kidney Dis, 63(4), 590-597. https://doi.org/10.1053/j.ajkd.2013.10.055

Hallan, S. I., Coresh, J., Astor, B. C., Asberg, A., Powe, N. R., Romundstad, S., . . Holmen, J. (2006). International comparison of the relationship of chronic kidney disease prevalence and ESRD risk. J Am Soc Nephrol, 17(8), 2275-2284. https://doi.org/10.1681/ASN.2005121273

Hooi, L. S., Ong, L. M., Ahmad, G., Bavanandan, S., Ahmad, N. A., Naidu, B. M., . . Yusoff, M. F. (2013). A population-based study measuring the prevalence of chronic kidney disease among adults in West Malaysia. Kidney Int, 84(5), 1034-1040. https://doi.org/10.1038/ki.2013.220

Imai, E., Horio, M., Watanabe, T., Iseki, K., Yamagata, K., Hara, S., . . Matsuo, S. (2009). Prevalence of chronic kidney disease in the Japanese general population. Clin Exp Nephrol, 13(6), 621-630. 
https://doi.org/10.1007/s10157-009-0199-x

Inaguma, D., Imai, E., Takeuchi, A., Ohashi, Y., Watanabe, T., Nitta, K., . . Chronic Kidney Disease Japan Cohort Study, G. (2017). Risk factors for CKD progression in Japanese patients: findings from the Chronic Kidney Disease Japan Cohort (CKD-JAC) study. Clin Exp Nephrol, 21(3), 446-456. https://doi.org/10.1007/s10157-016-1309-1

Ingsathit, A., Thakkinstian, A., Chaiprasert, A., Sangthawan, P., Gojaseni, P., Kiattisunthorn, K., . . Singh, A. K. (2010). Prevalence and risk factors of chronic kidney disease in the Thai adult population: Thai SEEK study. Nephrol Dial Transplant, 25(5), 1567-1575. https://doi.org/10.1093/ndt/gfp669

Jacobsen, F. K., Christensen, C. K., Mogensen, C. E., Andreasen, F., \& Heilskov, N. S. (1979). Pronounced increase in serum creatinine concentration after eating cooked meat. Br Med J, l(6170), 1049-1050.

Jha, V., Garcia-Garcia, G., Iseki, K., Li, Z., Naicker, S., Plattner, B., . . Yang, C. W. (2013). Chronic kidney disease: global dimension and perspectives. Lancet, 382(9888), 260-272. https://doi.org/10.1016/S0140-6736(13)60687-X

Kanazawa, M., Yoshiike, N., Osaka, T., Numba, Y., Zimmet, P., \& Inoue, S. (2005). Criteria and classification of obesity in Japan and Asia-Oceania. World Rev Nutr Diet, 94, 1-12. https://doi.org/10.1159/000088200

Keith, D. S., Nichols, G. A., Gullion, C. M., Brown, J. B., \& Smith, D. H. (2004). Longitudinal follow-up and outcomes among a population with chronic kidney disease in a large managed care organization. Arch Intern Med, 164(6), 659-663. https://doi.org/10.1001/archinte.164.6.659

Khaledifar, A., Gharipour, M., Bahonar, A., Sarrafzadegan, N., \& Khosravi, A. (2013). Association between Salt Intake and Albuminuria in Normotensive and Hypertensive Individuals. Int J Hypertens, 2013, 523682. https://doi.org/10.1155/2013/523682

Kim, S., Lim, C. S., Han, D. C., Kim, G. S., Chin, H. J., Kim, S. J., . . Kim, Y. S. (2009). The prevalence of chronic kidney disease (CKD) and the associated factors to CKD in urban Korea: a population-based cross-sectional epidemiologic study. J Korean Med Sci, 24 Suppl, S11-21. https://doi.org/10.3346/jkms.2009.24.S1.S11

Knight, E. L., Stampfer, M. J., Hankinson, S. E., Spiegelman, D., \& Curhan, G. C. (2003). The impact of protein intake on renal function decline in women with normal renal function or mild renal insufficiency. Ann Intern Med, 138(6), 460-467.

Lim, Banwell, C., Bain, C., Banks, E., Seubsman, S. A., Kelly, M., . . Sleigh, A. (2014). Sugar sweetened beverages and weight gain over 4 years in a Thai national cohort--a prospective analysis. PLoS One, 9(5), e95309. https://doi.org/10.1371/journal.pone.0095309

Lim, Kjellstrom, T., Sleigh, A., Khamman, S., Seubsman, S., Dixon, J., \& Banwell, C. (2009). Associations between urbanisation and components of the health-risk transition in Thailand. A descriptive study of 87,000 Thai adults. Glob Health Action, 2. https://doi.org/10.3402/gha.v2i0.1914

Lim, Seubsman, S., \& Sleigh, A. (2009). Validity of self-reported weight, height, and body mass index among university students in Thailand: Implications for population studies of obesity in developing countries. Popul Health Metr, 7, 15. https://doi.org/10.1186/1478-7954-7-15

Lin, J., \& Curhan, G. C. (2011). Associations of sugar and artificially sweetened soda with albuminuria and kidney function decline in women. Clin J Am Soc Nephrol, 6(1), 160-166. https://doi.org/10.2215/CJN.03260410

Lin, J., Hu, F. B., \& Curhan, G. C. (2010). Associations of diet with albuminuria and kidney function decline. Clin J Am Soc Nephrol, 5(5), 836-843. https://doi.org/10.2215/CJN.08001109

Martins, D., Tareen, N., Zadshir, A., Pan, D., Vargas, R., Nissenson, A., \& Norris, K. (2006). The association of poverty with the prevalence of albuminuria: data from the Third National Health and Nutrition Examination Survey (NHANES III). Am J Kidney Dis, 47(6), 965-971. https://doi.org/10.1053/j.ajkd.2006.02.179

Muntner, P., Coresh, J., Smith, J. C., Eckfeldt, J., \& Klag, M. J. (2000). Plasma lipids and risk of developing renal dysfunction: The atherosclerosis risk in communities study. Kidney Int, 58(1), 293-301. https://doi.org/10.1046/j.1523-1755.2000.00165.x

Murray, C. J., \& Lopez, A. D. (2013). Measuring the global burden of disease. N Engl J Med, 369(5), 448-457. https://doi.org/10.1056/NEJMra1201534

Papier, K., Jordan, S., Bain, C., D'Este, C., Thawornchaisit, P., Seubsman, S., \& Sleigh, A. (2017). Validity of Self-Reported Diabetes in a Cohort of Thai Adults. Glob J Health Sci, 9(7). 
https://doi.org/10.5539/gjhs.v9n7p1

Papier, K., Jordan, S., D'Este, C., Bain, C., Peungson, J., Banwell, C., . . Sleigh, A. (2016). Incidence and risk factors for type 2 diabetes mellitus in transitional Thailand: results from the Thai cohort study. BMJ Open, 6(12), e014102. https://doi.org/10.1136/bmjopen-2016-014102

Park, J. I., Baek, H., \& Jung, H. H. (2016). Prevalence of Chronic Kidney Disease in Korea: the Korean National Health and Nutritional Examination Survey 2011-2013. J Korean Med Sci, 31(6), 915-923. https://doi.org/10.3346/jkms.2016.31.6.915

Parving, H. H., Lewis, J. B., Ravid, M., Remuzzi, G., Hunsicker, L. G., \& investigators, D. (2006). Prevalence and risk factors for microalbuminuria in a referred cohort of type II diabetic patients: a global perspective. Kidney Int, 69(11), 2057-2063. https://doi.org/10.1038/sj.ki.5000377

Pechter, U., Ots, M., Mesikepp, S., Zilmer, K., Kullissaar, T., Vihalemm, T., . . Maaroos, J. (2003). Beneficial effects of water-based exercise in patients with chronic kidney disease. Int $J$ Rehabil Res, 26(2), 153-156. https://doi.org/10.1097/01.mrr.0000070755.63544.5a

Perkovic, V., Cass, A., Patel, A. A., Suriyawongpaisal, P., Barzi, F., Chadban, S., . . Neal, B. (2008). High prevalence of chronic kidney disease in Thailand. Kidney Int, 73(4), 473-479. https://doi.org/10.1038/sj.ki.5002701

Pinto-Sietsma, S. J., Mulder, J., Janssen, W. M., Hillege, H. L., de Zeeuw, D., \& de Jong, P. E. (2000). Smoking is related to albuminuria and abnormal renal function in nondiabetic persons. Ann Intern Med, 133(8), 585-591.

Pitayatienanan, P., Butchon, R., Yothasamut, J., Aekplakorn, W., Teerawattananon, Y., Suksomboon, N., \& Thavorncharoensap, M. (2014). Economic costs of obesity in Thailand: a retrospective cost-of-illness study. BMC Health Serv Res, 14, 146. https://doi.org/10.1186/1472-6963-14-146

Ramirez, S. P., McClellan, W., Port, F. K., \& Hsu, S. I. (2002). Risk factors for proteinuria in a large, multiracial, southeast Asian population. J Am Soc Nephrol, 13(7), 1907-1917.

Rizzetto, F., Leal, V. O., Bastos, L. S., Fouque, D., \& Mafra, D. (2017). Chronic kidney disease progression: a retrospective analysis of 3-year adherence to a low protein diet. Ren Fail, 39(1), 357-362. https://doi.org/10.1080/0886022X.2017.1282374

Roth, G. A., Huffman, M. D., Moran, A. E., Feigin, V., Mensah, G. A., Naghavi, M., \& Murray, C. J. (2015). Global and regional patterns in cardiovascular mortality from 1990 to 2013. Circulation, 132(17), 1667-1678. https://doi.org/10.1161/CIRCULATIONAHA.114.008720

Saldana, T. M., Basso, O., Darden, R., \& Sandler, D. P. (2007). Carbonated beverages and chronic kidney disease. Epidemiology, 18(4), 501-506. https://doi.org/10.1097/EDE.0b013e3180646338

Sasat, S., \& Bowers, B. J. (2013). Spotlight Thailand. Gerontologist, 53(5), 711-717. https://doi.org/10.1093/geront/gnt038

Schaeffner, E. S., Kurth, T., Curhan, G. C., Glynn, R. J., Rexrode, K. M., Baigent, C., . . Gaziano, J. M. (2003). Cholesterol and the risk of renal dysfunction in apparently healthy men. J Am Soc Nephrol, 14(8), 2084-2091.

Seubsman, S. A., Yiengprugsawan, V., Sleigh, A. C., \& the Thai Cohort Study, T. (2012). A large national Thai Cohort Study of the Health-Risk Transition based on Sukhothai Thammathirat Open University students. ASEAN J Open Distance Learn, 4(1).

Shoham, D. A., Durazo-Arvizu, R., Kramer, H., Luke, A., Vupputuri, S., Kshirsagar, A., \& Cooper, R. S. (2008). Sugary soda consumption and albuminuria: results from the National Health and Nutrition Examination Survey, 1999-2004. PLoS One, 3(10), e3431. https://doi.org/10.1371/journal.pone.0003431

Silverwood, R. J., Pierce, M., Thomas, C., Hardy, R., Ferro, C., Sattar, N., . . Data Collection, T. (2013). Association between younger age when first overweight and increased risk for CKD. J Am Soc Nephrol, 24(5), 813-821. https://doi.org/10.1681/ASN.2012070675

Sleigh, A. C., Seubsman, S. A., \& Bain, C. (2008). Cohort profile: The Thai Cohort of 87,134 Open University students. Int J Epidemiol, 37(2), 266-272. https://doi.org/10.1093/ije/dym161

Stengel, B., Tarver-Carr, M. E., Powe, N. R., Eberhardt, M. S., \& Brancati, F. L. (2003). Lifestyle factors, obesity and the risk of chronic kidney disease. Epidemiology, 14(4), 479-487. https://doi.org/10.1097/01.EDE.0000071413.55296.c4

Suleymanlar, G., Utas, C., Arinsoy, T., Ates, K., Altun, B., Altiparmak, M. R., . . Serdengecti, K. (2011). A 
population-based survey of Chronic REnal Disease In Turkey--the CREDIT study. Nephrol Dial Transplant, 26(6), 1862-1871. https://doi.org/10.1093/ndt/gfq656

Takamatsu, N., Abe, H., Tominaga, T., Nakahara, K., Ito, Y., Okumoto, Y., . . Doi, T. (2009). Risk factors for chronic kidney disease in Japan: a community-based study. BMC Nephrol, 10, 34. https://doi.org/10.1186/1471-2369-10-34

Tawatsupa, B., Yiengprugsawan, V., Kjellstrom, T., Berecki-Gisolf, J., Seubsman, S. A., \& Sleigh, A. (2013). Association between heat stress and occupational injury among Thai workers: findings of the Thai Cohort Study. Ind Health, 51(1), 34-46.

Thawornchaisit, P., De Looze, F., Reid, C. M., Seubsman, S. A., Sleigh, A., \& Thai Cohort Study, T. (2013a). Validity of self-reported hypertension: findings from the Thai Cohort Study compared to physician telephone interview. Glob J Health Sci, 6(2), 1-11. https://doi.org/10.5539/gjhs.v6n2p1

Thawornchaisit, P., de Looze, F., Reid, C. M., Seubsman, S. A., Sleigh, A. C., \& Thai Cohort Study, T. (2013b). Health risk factors and the incidence of hypertension: 4-year prospective findings from a national cohort of 60 569 Thai Open University students. BMJ Open, 3(6). https://doi.org/10.1136/bmjopen-2013-002826

Thawornchaisit, P., de Looze, F., Reid, C. M., Seubsman, S. A., Tran, T. T., Sleigh, A., \& Thai Cohort Study, T. (2015). Health-Risk Factors and the Prevalence of Chronic Kidney Disease: Cross-Sectional Findings from a National Cohort of 87,143 Thai Open University Students. Glob J Health Sci, 7(5), 59-72. https://doi.org/10.5539/gjhs.v7n5p59

Tsai, C. W., Lin, S. Y., Kuo, C. C., \& Huang, C. C. (2017). Serum Uric Acid and Progression of Kidney Disease: A Longitudinal Analysis and Mini-Review. PLoS One, 12(1), e0170393. https://doi.org/10.1371/journal.pone.0170393

Vart, P., Gansevoort, R. T., Coresh, J., Reijneveld, S. A., \& Bultmann, U. (2013). Socioeconomic measures and CKD in the United States and The Netherlands. Clin J Am Soc Nephrol, 8(10), 1685-1693. https://doi.org/10.2215/CJN.12521212

Vivante, A., Golan, E., Tzur, D., Leiba, A., Tirosh, A., Skorecki, K., \& Calderon-Margalit, R. (2012). Body mass index in 1.2 million adolescents and risk for end-stage renal disease. Arch Intern Med, 172(21), 1644-1650. https://doi.org/10.1001/2013.jamainternmed.85

Wakabayashi, M., McKetin, R., Banwell, C., Yiengprugsawan, V., Kelly, M., Seubsman, S. A., . . Thai Cohort Study, T. (2015). Alcohol consumption patterns in Thailand and their relationship with non-communicable disease. BMC Public Health, 15, 1297. https://doi.org/10.1186/s12889-015-2662-9

Webb, P., \& Bain, C. (2011). Essential Epidemiology: An Introduction for Students and Health Professionals (2 ed.): Cambridge University Press.

Weiner, D. E., Tighiouart, H., Elsayed, E. F., Griffith, J. L., Salem, D. N., \& Levey, A. S. (2008). Uric acid and incident kidney disease in the community. $J$ Am Soc Nephrol, 19(6), 1204-1211. https://doi.org/10.1681/ASN.2007101075

Wen, C. P., Cheng, T. Y., Tsai, M. K., Chang, Y. C., Chan, H. T., Tsai, S. P., . . Wen, S. F. (2008). All-cause mortality attributable to chronic kidney disease: a prospective cohort study based on 462293 adults in Taiwan. Lancet, 371(9631), 2173-2182. https://doi.org/10.1016/S0140-6736(08)60952-6

White, S. L., McGeechan, K., Jones, M., Cass, A., Chadban, S. J., Polkinghorne, K. R., . . Roderick, P. J. (2008). Socioeconomic disadvantage and kidney disease in the United States, Australia, and Thailand. Am J Public Health, 98(7), 1306-1313. https://doi.org/10.2105/AJPH.2007.116020

Xie, Y., \& Chen, X. (2008). Epidemiology, major outcomes, risk factors, prevention and management of chronic kidney disease in China. Am J Nephrol, 28(1), 1-7. https://doi.org/10.1159/000108755

Xue, C., Ye, X. D., Li, W., Peng, Q., Ding, H. Y., Zhang, Y. H., . . Liao, Y. H. (2013). Prevalence of chronic kidney disease in Jing adults in China: a village-based study. Clin Nephrol, 79(1), 50-56. https://doi.org/10.5414/CN107511

Xue, L., Lou, Y., Feng, X., Wang, C., Ran, Z., \& Zhang, X. (2014). Prevalence of chronic kidney disease and associated factors among the Chinese population in Taian, China. BMC Nephrol, 15, 205. https://doi.org/10.1186/1471-2369-15-205

Zhang, L., Wang, F., Wang, L., Wang, W., Liu, B., Liu, J., . . Wang, H. (2012). Prevalence of chronic kidney 
disease in China: a cross-sectional survey. Lancet, $379(9818)$, 815-822. https://doi.org/10.1016/S0140-6736(12)60033-6

Zhang, L., Zhang, P., Wang, F., Zuo, L., Zhou, Y., Shi, Y., ... Wang, H. (2008). Prevalence and factors associated with CKD: a population study from Beijing. Am J Kidney Dis, 51(3), 373-384. https://doi.org/10.1053/j.ajkd.2007.11.009

Zhang, L., Zuo, L., Xu, G., Wang, F., Wang, M., Wang, S., . . Wang, H. (2007). Community-based screening for chronic kidney disease among populations older than 40 years in Beijing. Nephrol Dial Transplant, 22(4), 1093-1099. https://doi.org/10.1093/ndt/gfl763

\section{Copyrights}

Copyright for this article is retained by the author(s), with first publication rights granted to the journal.

This is an open-access article distributed under the terms and conditions of the Creative Commons Attribution license (http://creativecommons.org/licenses/by/4.0/). 